\title{
Description of the third larval instar and pupa of Geniates barbatus Kirby (Coleoptera, Scarabaeidae, Rutelinae)
}

\author{
Juares Fuhrmann ${ }^{1}$
}

${ }^{1}$ Museu de Zoologia, Universidade de São Paulo, 04218-970 São Paulo-SP, Brazil. jufuhrmann@gmail.com

\begin{abstract}
Description of the third larval instar and pupa of Geniates barbatus Kirby (Coleoptera, Scarabaeidae, Rutelinae). The last larval instar and pupa of the Neotropical Geniatini Geniates barbatus Kirby, 1819 are described and illustrated. Biological notes and a key to the third instar larvae of Neotropical Rutelinae are also provided.
\end{abstract}

KEYWORDS. Aspidolea, Brazil; Cyclocephala; Insecta; Scarabaeoidea; white grubs.

The nominotypical genus Geniates Kirby, 1819 is one of the 13 genera of the Neotropical tribe Geniatini. Geniates is recorded from northern Panama to central Chile and southern Argentina and comprises 39 species (Jameson \& Hawkins 2005). The type species Geniates barbatus Kirky, 1819 has economical importance for cultures of Eucalyptus robusta Sm., E. tereticornis Sm. (Myrtaceae) and Cammellia sinensis Kuntze (Ternstroemiaceae) (tea, “chá”) in Brazil. The adult has been observed defoliating those trees and also a number of other plants: Anacardium occidentale L. (Anacardiaceae) (cashew, "cajueiro"), Cocos nucifera L. (Arecaceae) (coconut palm, "coqueiro"), Eugenia pitanga (O. Berg) Nied. (Myrtaceae) (Surinam cherry, "pitangueira"), Mangifera indica L. (Anacardiaceae) (mango tree, "mangueira"), Rosa spp. (Rosceae), Psidium guajava L. (Myrtaceae) (guava tree, "goiabeira") and Terminalia sp. (Combretaceae) (Anjos \& Majer 2003; Costa Lima 1953; Silva et al. 1968).

Despite the economic importance of this insect group, the systematics of Geniatini and the morphology of its immature stages are poorly known (Jameson \& Hawkins 2005; PardoLocarno et al. 2006). Although Ohaus (1900) recorded female pupae of Geniates barbatus and G. castaneus Burmeister, 1844, about $50 \mathrm{~cm}$ deep in the soil, their immature stages remain undescribed. In fact, the immature of only one species of Geniatini is known: Leucothyreus femoratus Burmeister, 1844, described by Pardo-Locarno et al. (2006). Therefore the description of the larva and pupa of Geniates presented here represents an important addition to the knowledge of the immatures of Sacarabaeidae and to the taxonomy of Rutelinae.

\section{MATERIAL AND METHODS}

Ten larvae of Geniates barbatus were collected about 10 $\mathrm{cm}$ deep in the soil covered by grass (Poaceae) in two different localities of São Paulo state, Brazil. Seven larvae were collected in Granja Viana, a locality of the Cotia municipality; other three larvae were collected in Estação Biológica de
Boracéia, a forest reserve in Salesópolis municipality. Larvae were reared in the laboratory of the Instituto Biológico de São Paulo (IBSP) and maintained in covered plastic pots with rich humus soil until the adult emergence.

Five larvae and two pupae were killed in boiling water and fixed in ethanol $70 \%$. The specimens are deposited in the collection of the Museu de Zoologia da Universidade de São Paulo, state of São Paulo, Brazil (MZSP).

The specimens were examined using a stereomicroscope Carl Zeiss Stemi SV6 and microscope Carl Zeiss Axioskop. Illustrations are produced via camera lucida attached in both equipments. Measurements were obtained by ocular micrometer.

The shape of all spiracle plates and bulla has been found to be important for a more precise identification. For this reason, the bulla ratio (dorsoventral diameter of bulla/distance of the lobes of the respiratory plate) was measured to all spiracles.

The terminology of immature morphology follows Böving (1936), Carlson (1991) and Lawrence (1991).

\section{RESULTS}

\section{Geniates barbatus Kirby, 1819}

\section{Third instar larva (Figs. 1-23)}

Description. Body (Fig. 1) length: 11.9-12.2 mm.

Head (Figs. 8-11, 15) width: 4.9-5.0 mm. Epicranial and epistomal sutures present. Epicranium surface slightly rugose; two lateromedial dark spots present; each side with 5 dorsoepicranial setae (des), one lateroepicranial seta (les), 2 anteroepicranial setae (aes), 2 externoepicranial setae (ees), 7 ventroepicranial setae (ves), 3 posterofrontal setae $(p f s)$, and one externofrontal seta (efs). Stemmata present. Clypeus and labrum rugopunctate; each side with one anteroclipeal seta $(a c s), 2$ lateroclypeal setae (lcs), one posterolabral seta $(\mathrm{pls}), 4$ laterolabral setae $(\mathrm{lls})$, one mediolabral seta $(\mathrm{mls})$, and 2 anterolabral setae (als). Epipharynx (Fig. 14). 


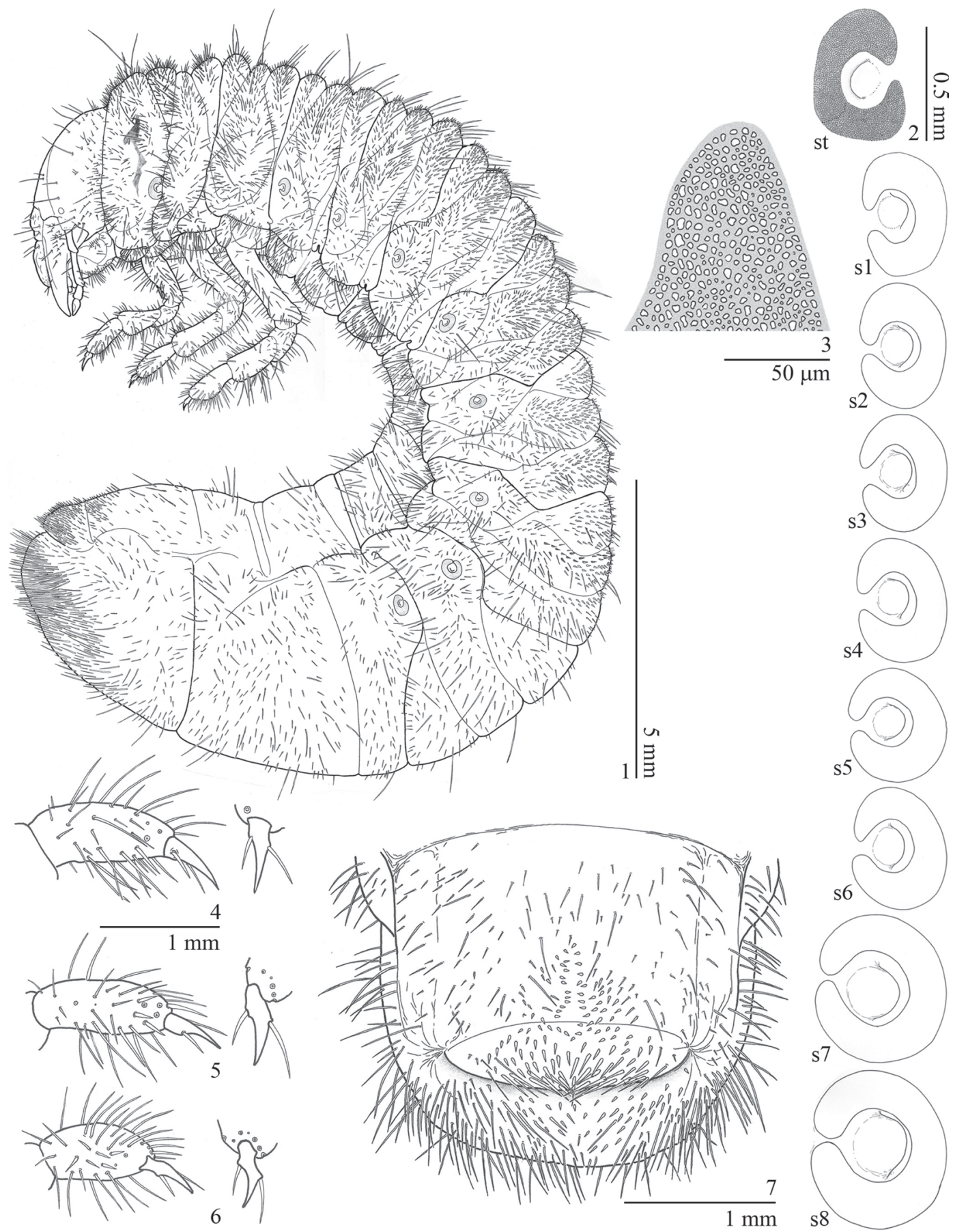

Figs. 1-7. Geniates barbatus Kirby; third instar larva. 1, lateral; 2, spiracles; 3, detail of the dorsal arm of thoracic spiracle; 4-6, external pro-, meso- and metatarsungulus with dorsal detail of the claw; 7, urosternite X. st, thoracic spiracle; s1-8, abdominal spiracle 1-8.

Plegmatium with 16 plegmata, each plegma with one external seta of the acanthoparia; proplegmatia absent. Epizygum present and clithra absent. Corypha small, with 16-20 setae. Haptomerum prominent; zygum beak-like with apex 5toothed; heli absent. Chaetoparia with sparse sensilla, right side with 50 internal stout setae and 54 external thin setae; left side with 9-11 anterior stout setae, 66 posteroexternal thin setae; phobae absent. Pedium smooth. Laeotorma short; pterotorma rounded and fused to laeotorma; epitorma nar- row, depressed; dexiotorma narrow and internally projected. Haptolachus with 4 right setae and 13 left seate; crepis present; nesium internum (sensorial cone) prominent; nesium externum (sclerotized plate) sharply acuminated. Right mandible (Figs. 18-20) with 2 anterodorsal setae, 4 dorsal anteromolar setae, and 5-7 ventral brush-like setae; scissorial area with a simple tooth and a posterior notch; molar area with 3 transversally ridged lobes, brustia with 6 setae; ventral side with enlogate-oval stridulatory area comprised of 

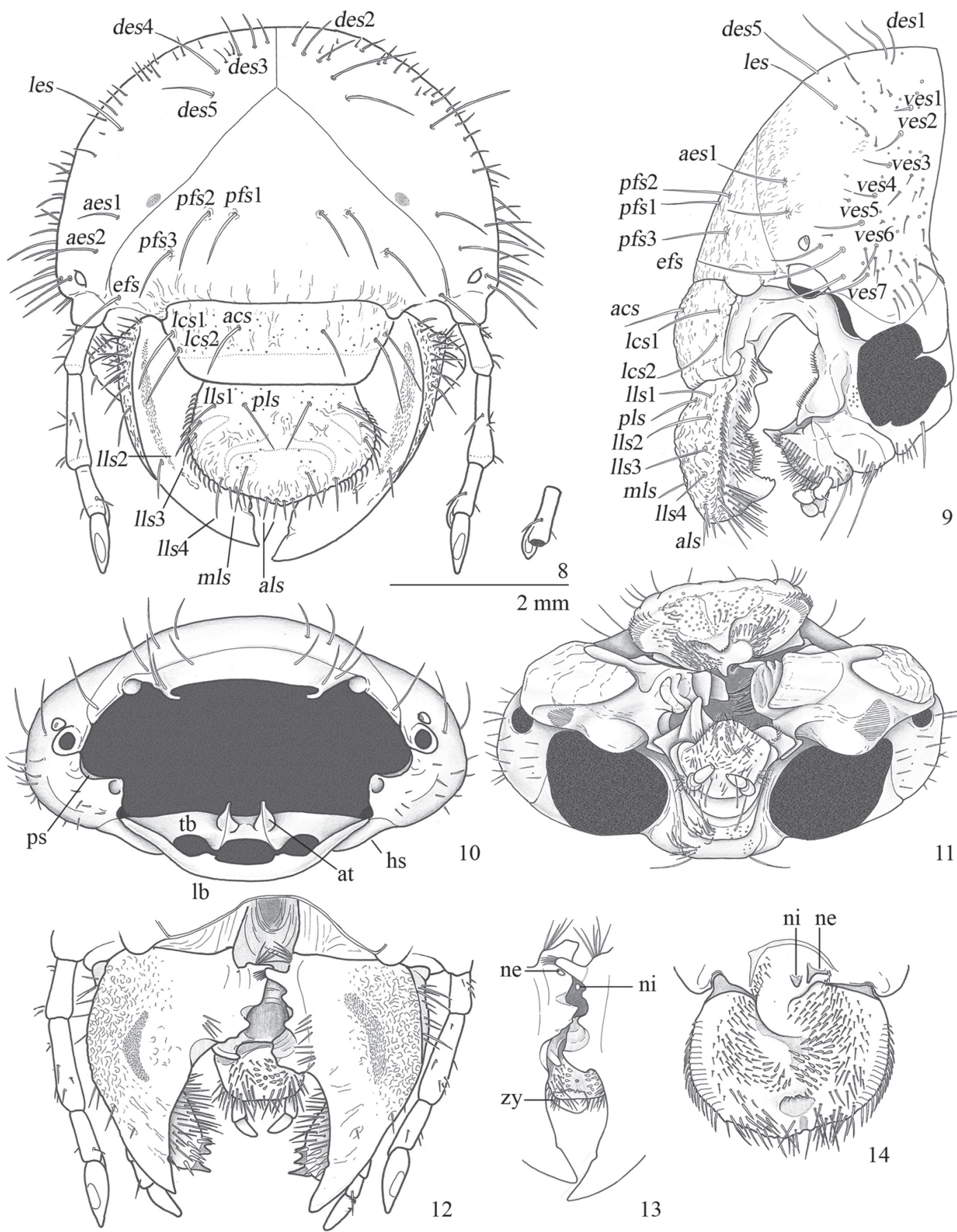

13

Figs. 8-14. Geniates barbatus Kirby; head. 8, dorsum; 9, lateral; 10, frontal detail of peristomium; 11, frontal detail of preoral cavity; 12-13, dorsum detail of preoral cavity; 13, detail of mandibles closure with position of epipharynx ornamentation (red); 14, epipharynx. Nomenclature of setae (italic) in the text. at, anterior tentorial arm; hs, hypostoma; lb, labium-maxillae base; ne, nesium externum; ni, nesium internum; ps, pleurostoma; tb, tentorial bridge; zy, zygum.

approximately 43 progressively less spaced costulae; dorsal side with roughly rugose area; ventral process prominent. Left mandible (Figs. 21-23) with similar chaetotaxy to right one, but the dorsal anteromolar with a row of 11 setae; scissorial area similar to right one; molar area with 5 transversally ridged lobes, brustia with 14 setae; acia prominent, truncated and with 10 apical setae; ventral stridulatory area similar to the right one and comprised of approximately
38 costulae; rugosity dorsal area and ventral process similar to the right mandible. Maxillae (Figs. 15-17) symmetrical; cardo setose and 3-lobed; stipes setose, with the stridulatory area formed by a row of 10 teeth and an anterior truncated process; mala setose, anterior and internal setae stout, dorsal side with longitudinal depression between galea and lacinia, galea with a well developed uncus and lacinia with 3 unci; palpus 4-segmented, segment III with one external seta. La- 

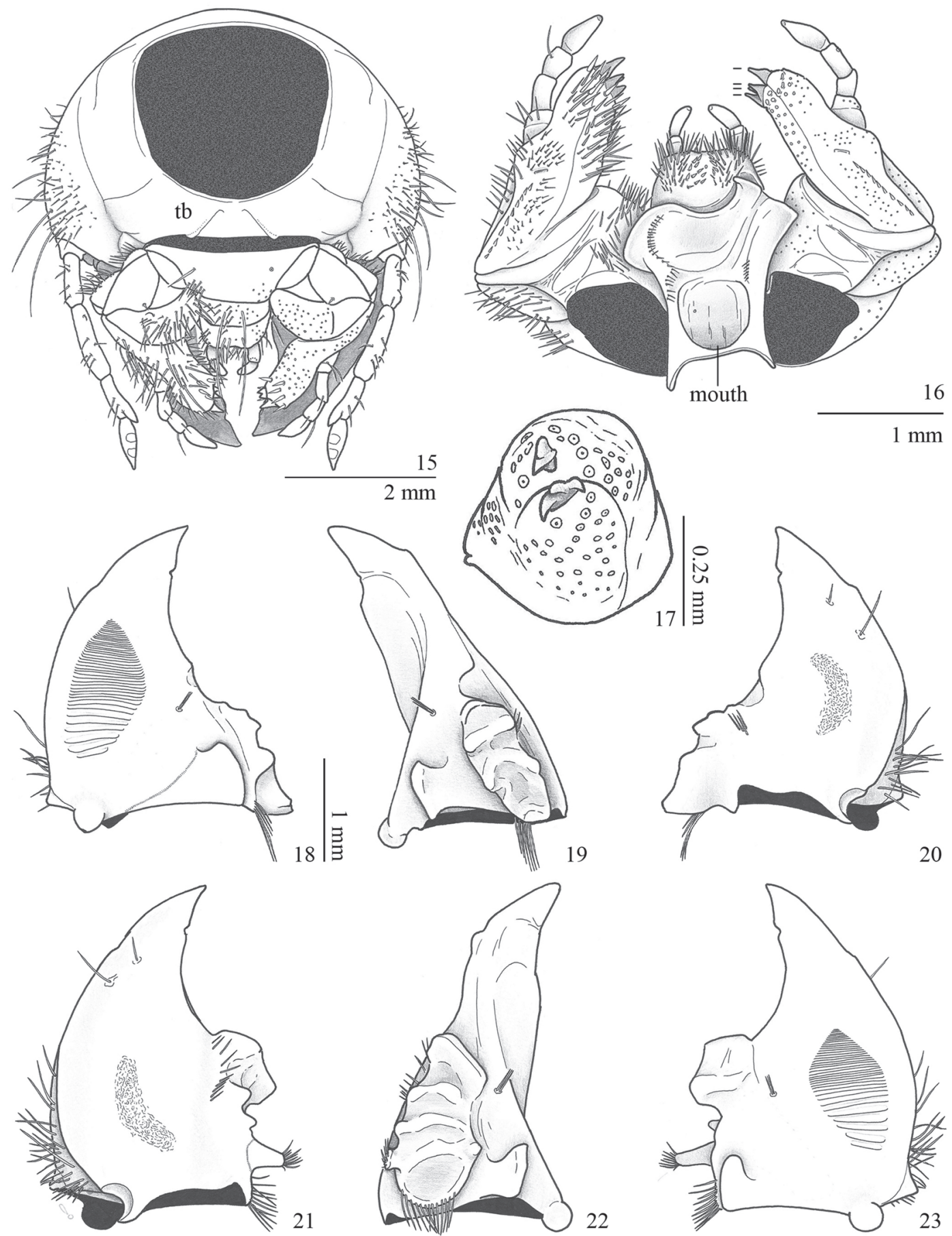

Figs. 15-23. Geniates barbatus Kirby; head. 15,venter; 16, dorsum of maxillae and labium; 17, apical detail of mala; 18-20 left mandible (venter, internal face, dorsum); 21-23 right mandible (dorsum, internal face, venter). tb, tentorial bridge.

bium (Figs. 15-16): submentum with a group of setae on the anterior angles and two stout setae on medial area; each mentum and prementum with 2 long medial setae and sparse short setae; palpi 2-segmented, apex of segment I with minute setae; ligula with dense external thin setae and stout internal setae flanking a small smooth central area with a sensilla. Hypopharynx (Fig. 16) with an asymmetrical sclerite with a right prominent tooth, left side with longitudinal row of 24
25 setae, and right side with a row of 6 setae. Antennae 4segmented: I-II with sparse setae; III with one dorsal seta, 2 ventral setae, and a ventral process that have a dorsal spot; IV with one dorsal large spot, and 2 ventral small spots.

Thorax. Prothorax with a lateral sclerite and dorsally simple lobed; meso- and metathorax dorsally 3-lobed, thoracic dorsal lobes with transversal row of sparse long setae mixed with abundant small setae. Spiracle (Figs. 2-3) with C shaped respiratory 
plate, major diameter of bulla approximately three times longer than distance of the lobes of the respiratory plate. Legs (Figs. 4-6) densely setose; claws with 2 lateral setae on each side.

Abdomen with 10 segments; I-VII each forming 3 dorsal lobes, pubescence similar to the meso- and metathorax, I-VI also with small tooth-like setae; IX with sparse setae; $\mathrm{X}$ with sparse setae except on the posterior half of dorsum. Spiracles (Fig. 2) similar those of thorax, first segment with the bulla ratio equal 1.7, in segments II-VI ratio about 4.3, in segments VII-VIII bigger than the precedents, and with ratio about17.5. Raster (Fig. 7) with septula poorly defined; palidia formed by 2 longitudinal irregular rows of 12-16 small tooth-like setae, and extended on ventral anal lobe. Anal opening transverse and weakly curved.

Material examined. BRAZIL, state of São Paulo, Cotia, Granja Viana, 09.viii.2009, G. Francfort leg., 4 larvae, 1 third instar exuvia (MZSP), Salesópolis, Estação Biológica de Boracéia, 27.iii.2012, D. C. Bená \& J. Fuhrmann leg., 1 larva (MZSP).

\section{Pupa (Figs. 24-28)}

Description. Length: $19 \mathrm{~mm}$, maximal width: $0.9 \mathrm{~mm}$. Body (Figs. 24-26) oblong and light yellow with spiracles and dioneiform organs reddish brown and sclerotized. Integument macroscopically smooth and glabrous but covered by a thin and short microscopic pubescence, which gives a velvety appearance to the surface (50x of magnification); meso- and metanotum with medial area with slightly longer pubescence; apex of urotergite 9 densely pubescent.

Head (Fig. 27). Vertex visible from dorsal view. Frons smooth. Epistomal suture complete. Canthus large and weakly distinct. Eyes compressed between the anterior angles of pronotum and antennae. Antennae almost rectangular on lateral view. Clypeus transverse with curved lateral borders. Mandibles, malae, and palpi tubercle-like. Labium slightly convex in female and semisferical in males.

Thorax. Pronotum trapezoid with rounded lateral borders. Prosternal posterior process small and visible behind procoxae. Thoracic spiracle present in cavity formed between the anterior and medial legs, hypomeron, and elytral thecae basis. Mesonotum shorter than pro- or metanotum; scutellar area slightly backwardly projected. Disc of metaventrite longer than wide, and without any evident anterior or posterior process. Pterothecae I superposed to pterothecae II, and anterior margin subposed by medial leg. Pterotheca II covering proximal half of posterior leg. Pro-, meso- and metacoxae contiguous medially; spurs of meso- and metatibiae internal and tubercle-like; metafemur-tibial junction slightly visible for above; male protarsus larger than female tarsus.

Abdomen. Spiracles I-IV oval and with sclerotized ring; I concealed by pterothecae II; spiracle V-VIII represented by cuticular evagination. Segment I only represented by the tergite. Dioneiform organs present in the mid-base and the midapex between segments I-II, II-III, III-IV, IV-V, V-VI. Tergite IX triangular and with large latero-posterior lobes; apex of lobes slightly prominent; urogomphi absent. Sternite II vis- ible medially, female ventrite VIII with medial genital pore, male ventrite VIII with genital ampulla (Fig. 28).

Material examined. BRAZIL, state of São Paulo, Cotia, Granja Viana, 09.viii.2009, G. Francfort leg, 1 female pupa, 1 female pupal exuvia (MZSP), Salesópolis, Estação Biológica de Boracéia, 27.iii.2012, D. C. Bená \& J. Fuhrmann leg., 1 male pupa (MZSP).

Biological notes. Larvae of G. barbatus collected in Cotia were associated with larvae of Cyclocephala signaticollis Burmeister, 1847 (Dynastinae, Cyclocephalini) (described by Morelli 1991), and those collected in Estação Biológica de Boracéia were associated with larvae of Aspidolea pelioptera (Burmeister, 1847) (Dynastinae, Cyclocephalini). The three species were found in superficial soil (about 10 $\mathrm{cm}$ deep) covered by grass, consuming the grass roots and soil with high humus content. The association is probably only a gregarious behavior around the food resources.

In the laboratory, one larva of G. barbatus was observed consuming a cadaver of a conspecific larva. It is not known if the larva killed the individual being consumed, but active sporadic cannibalism behavior has been reported for some scarab larvae (e.g. Soltani et al. 2008). On the other hand, some scarab larvae seem to attack and kill other larvae without feeding on them (e.g. Wightman 1974).

\section{Key to the third instar larvae of Neotropical Rutelinae (modified from Pardo-Locarno et al. 2006)}

1. Last antenomere with 2 or more dorsal sensory spots .... Rutelini (see Jameson \& Morón 2001)

1 ' Last antennomere with one dorsal sensory spot ............ 2

2. Epipharynx with prominent haptomerum, without heli... 3

2'Epipharynx with weakly prominent, rounded haptomerum, followed by transverse row of 2-4 stout heli Anomalini (see Micó et al. 2003)

3. Palidia absent. Maxillary stridulatory area formed by 11 short teeth with similar shape and size

Anoplognathini ...... Platycoelia Dejean

3' Palidia present. Maxillary stridulatory formed by 10 teeth with similar or different shape and size

Geniatini .......... 4

4. Lacinia with 2 unci. Plegmatia absent. Left mandible with acuminate acia. Respiratory plate V-VIII with progressively shorter diameter. Palidia short, formed by $2-4$ pali . Leucothyreus femoratus Burmeister

4' Lacinia with 3 unci. Plegmatia present. Left mandible with truncate acia. Respiratory plate V-VIII with progressively bigger diameter. Palidia long, formed by $12-16$ pali ...... Geniates barbatus Kirby

\section{DISCUSSION}

Pardo-Locarno et al. (2006) characterized the Geniatini larvae based on Leucothyreus femoratus. The description of G. barbatus updates the larval diagnosis of Geniatini to: last 

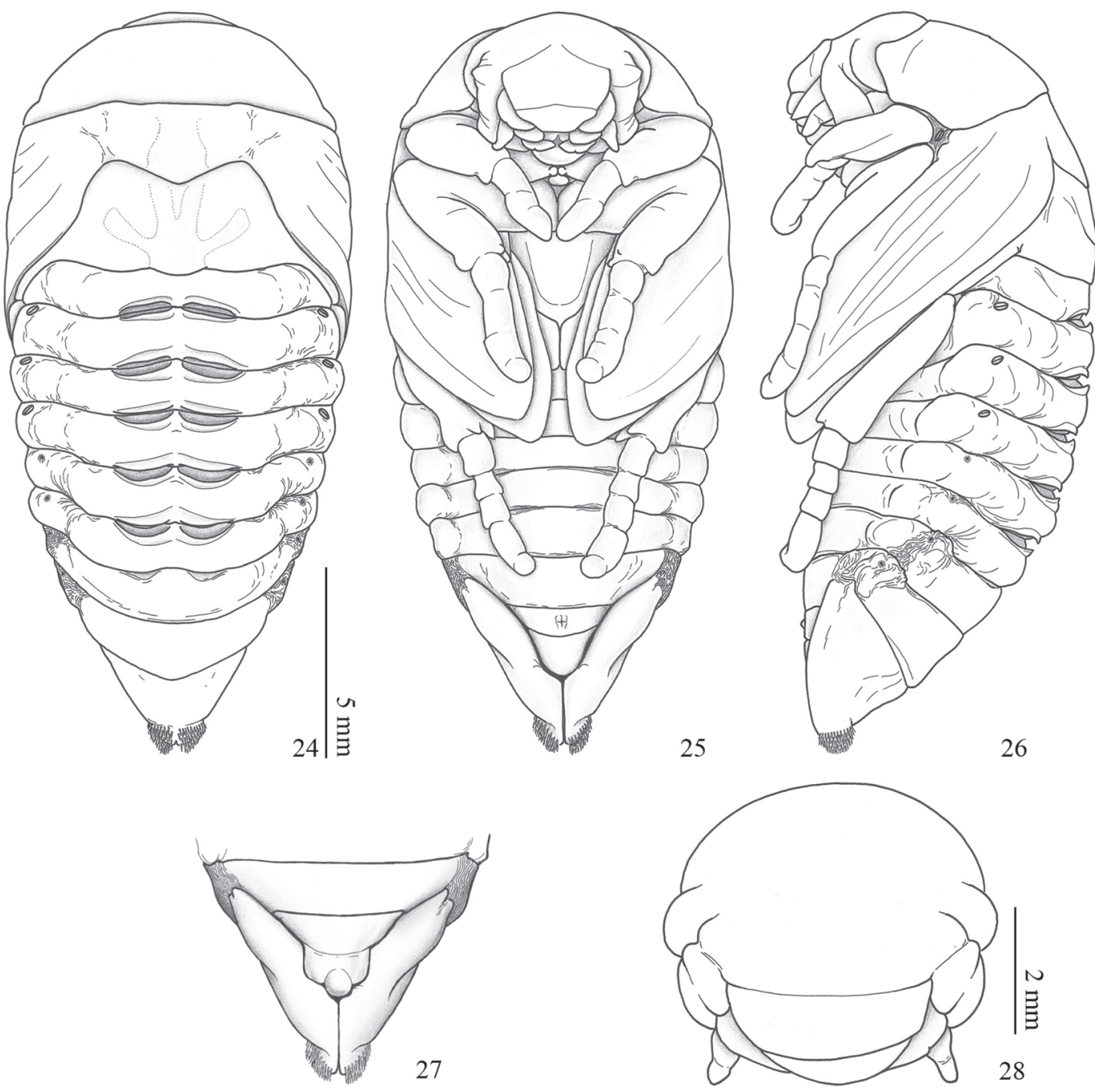

Figs. 24-28. Geniates barbatus Kirby; pupa. 24, dorsum; 25, venter; 26, lateral; 27, male ventral terminalia; 28, head dorsum.

antenomere with one dorsal sensorial spot (Rutelini have two or more; see Jameson \& Morón 2001); epipharynx without heli (Anomalini have 2 to 4 well developed heli; see Micó et al. 2003; in other Rutelinae tribes heli is absent, because unciform or teeth-like setae are not considered as heli sensu Böving 1936 and Ritcher 1948); palidia present, but reduced (raster of Anoplognathini without palidia).

This study shows that the larvae of Geniatini seem to be more similar to Anoplognathini than to Rutelini or Anomalini. Pardo-Locarno et al. (2006) proposed the separation between Geniatini (based on L. femoratus) and Anoplognatini (based on two species of Platycoelia Dejean, 1833, the single genus with described larvae in Anoplognathini; see Paucar-Cabrera \& Smith 2002) using maxillary and palidial characters, as follows: Geniatini have lacinia with two unci and the maxillary stridulatory organ formed by heterogeneous teeth; meanwhile Anoplognathini have lacinia with three unci and homogeneous teeth in the maxillary stridulatory organ. Regarding these characters, the larvae of G. barbatus resemble more the larvae of Platycoelia than the larvae of L. femoratus.
Another common characteristic between G. barbatus and Platycoelia is the last abdominal spiracles larger than the first ones. On other hand, Platycoelia and L. femoratus have the left mandible with acuminated and glabrous acia and last antenomere with two ventral spots.

Larvae of G. barbatus and L. femoratus can be differentiated from each other by the following characters (characters of L. femoratus in parentheses): epipharynx with (without) plegmatia; left mandible with a truncated acia with apical setae (spine-like and glabrous); maxillary stridulatory organ with one anterior truncate process and 10 posterior acuminated teeth (with one anterior truncated process and 10 posterior teeth, the anterior five truncated); lacinia with three unci (with two unci); last antenomere with one ventral spot (two ventral spots); abdominal spiracles VII and VIII enlarged (I-VIII decreasing in length).

The pupae of G. barbatus and L. femoratus have the apex of urotergite IX prominent and upward deflected. This differentiates known Geniatini pupae from other known pupae of Rutelinae, with have the urosternite IX apex directed posteri- 
orly. Moreover, the urotergite IX pubescence of G. barbatus and $L$. femoratus is relatively longer than in others Rutelinae.

Pupae of G. barbatus and L. femoratus can be differentiated from each other by the following characters (characters of $L$. femoratus in parentheses): apex of metatibiae exposed in dorsal view (hidden by the pterothecae); dioneiform organs relatively longer (shorter); urotergite VIII transverse and shorter than urosternite IX (semispherical and longer than urotergite IX).

\section{ACKNOWLEDGMENTS}

I would like to thank Coordenação de Aperfeiçoamento de Pessoal de Nivel Superior (CAPES) for grant support at the beginning of this project; Fundação de Amaparo à Pesquisa do Estado de São Paulo (FAPESP) (2011/20001-6) for a doctorate grant; Sônia A. Casari (MZSP), Sergio Ide (IBSP), Miguel A. Morón (Instituto de Ecologia, A.C.; Mexico), Sergio A. Vanin (Departamento de Zoologia, Universidade de São Paulo), Bruno A. S. de Medeiros (Museum of Comparative Zoology, Harvard University) and the anonymous reviewers for the valuable corrections and suggestions, and Gisele Sales Francfort and Daniela de Cassia Bená for helping with the material sampling.

\section{REFERENCES}

Anjos, N. \& Majer, J.D. 2003. Leaf-eating beetles in Brazilian eucalypt plantations. School of Environmental Biology Bulletin 23: iv +33 p.

Böving, A.G. 1936. Description of the larva of Plectris aliena Chapin and explanation of new terms applied to the epipharynx and raster. Proceedings of the Entomological Society of Washington 38: 169-185.

Carlson, D.C. 1991. Scarabaeidae (Scarabaeoidea) (including Acanthoceridae, Ceratocanthidae, Cetoniidae, Diphllostomatidae, Geotrupidae, Glaphiridae, Hybosoridae, Pleocomidae, Trogidae, etc.), p. 377-384. In: Stehr, F.W. (ed.). Immature insects, v. 2. Dubuque, Kendall/Hunt Publishing Company, xvi+975 p.
Costa Lima, A.D. 1953. Insectos do Brasil. $8^{\circ}$ tomo. Coleópteros, $2^{\mathrm{a}}$ parte. Rio de Janeiro, Escola Nacional de Agronomia, Serie Didática no. 10, 323 p.

Jameson, M.L. \& Hawkins, S.J. 2005. Synopsis of the genera of Geniatini (Coleoptera: Scarabaeidae: Rutelinae) with an annotated catalog of species. Zootaxa 874: 1-76.

Jameson, M.L. \& Morón, M.A. 2001. Descriptions of the larvae of Chlorota cincticollis Blanchard and Chasmodia collaris (Blanchard) (Scarabaeidae: Rutelinae: Rutelini) with a key to the larvae of the American genera of Rutelini. The Coleopterists Bulletin 55: 385-396.

Lawrence, J.F. 1991. Larval morphology, p. 146-177. In: Stehr, F.W. (ed.). Immature insects, v. 2. Dubuque, Kendall/Hunt Publishing Company, $\mathrm{xvi}+975 \mathrm{p}$.

Micó, E., Morón, M.A. \& Galante, E. 2003. New larval descriptions and biology of some New World Anomalini beetles (Scarabaeidae: Rutelinae). Annals of the Entomological Society of America 96: 597-614.

Morelli, E. 1991. Descripción de la larva y de la pupa de Cyclocephala signaticollis Burmeister, 1847 (Coleoptera: Scarabaeidae: Dynastinae) y observaciones sobre su biología. Elytron, supplement 5: 189-195.

Ohaus, F. 1900. Bericht uber eine entomologische Reise nach Centralbrasilien. Stettiner Entomologische Zeitung 61: 164-191, 193-274.

Pardo-Locarno, L.C., Morón, M.A. \& Lerma, J.M. 2006. Descripción de los estados inmaduros de Leucothyreus femoratus Burmeister (Coleoptera: Melolonthidae: Rutelinae: Geniatini) con notas sobre su biologia e importancia agrícola en Colombia. Folia Entomologica Mexicana 45: 179-193.

Paucar-Cabrera, A. \& Smith, A.B.T. 2002. Larval descriptions for the Neotropical genus Platycoella (Coleoptera: Scarabaeidae: Rutelinae: Anoplognathini). The Coleopterists Bulletin 56: 438-445.

Ritcher, P.O. 1948. Descriptions of the larvae of some ruteline beetles with keys to tribes and species (Scarabaeidae). Annals of the Entomological Society of America 41: 206-212.

Silva, A.G.A., Gonçalves, C.R., Galvão, D.M., Gonçalves, A.J.L., Gomes, J., Silva, M.N. \& Simoni, L. 1968. Quarto catálogo dos insetos que vivem nas plantas do Brasil, seus parasitos e predadores. Part 2, Tomo 1, insetos, hospedeiros e inimigos naturais. Rio de Janeiro, Ministério da Agricultura, $622 \mathrm{p}$.

Soltani, R., Chaied, I. \& Hamouda M.H.B. 2008. The life cycle of the root borer, Oryctes agamemnon, under laboratory conditions. Journal of Insect Science 8: 1-6.

Wightman, J.A. 1974. Rearing Costelytra zealandica (Coleoptera: Scarabaeidae). 4. Some effects of different larval densities and food availability on larval survival and weight change. New Zealand Journal of Zoology 1: 217-223. 